Article

\title{
Issues Regarding the Design Intervention and Conservation of Heritage Areas: The Historical Pedestrian Streets of Kuala Lumpur
}

\author{
Ahmed Bindajam ${ }^{1}$, Fadrul Hisham ${ }^{2}$, Nashwan Al-Ansi ${ }^{3}$ and Javed Mallick ${ }^{4, *}$ \\ 1 Department of Architecture and Planning, College of Engineering, King Khalid University, \\ Abha 61411, Saudi Arabia; abindajam@kku.edu.sa \\ 2 Faculty of Design and Architecture, Universiti Putra Malaysia, Seri Kembangan 43400, Selangor, Malaysia; \\ fadrulhisham@live.com \\ 3 Faculty of Architecture and Planning, Qassim University, Al Qassim 51452, Saudi Arabia; n.alansi@qu.edu.sa \\ 4 Department of Civil Engineering, College of Engineering, King Khalid University, Abha 61411, Saudi Arabia \\ * Correspondence: jmallick@kku.edu.sa; Tel.: +966-172-428-439; Fax: +966-172-418-152
}

Received: 17 April 2020; Accepted: 6 May 2020; Published: 14 May 2020

check for updates

\begin{abstract}
This study focused on the areas of Petaling Street and Jalan Hang Kasturi, Kuala Lumpur, in a historical enclave that is well known locally for its cultural, architectural, and historical interest that is worth preserving and conserving. To fulfill the purpose of enhancing the areas, the local authority introduced a covered pedestrian street, which is said to be more convenient for shoppers, considering the tropical climate of Kuala Lumpur. This effort is believed to have been done without any consultation with heritage conservators and activists, thus invoking a debate regarding its many pros and cons. This study examined the arguments concerning the intervention in the heritage area from various groups of stakeholders that are directly involved. Furthermore, this paper presents the method of implementation used by the local authority when executing a conservation project. The collection of primary and secondary data in the form of surveys and interviews with the professionals, traders, and officials in the local area was carried out. The findings show that the majority of the respondents had no objection to the modern intervention in the Heritage Enclave, including the roofing structure, except for its design. This study also found that the intervention did not affect the heritage value of the place, but at the same time, brought concerns regarding the extemporaneous method taken by the local authority when implementing the project.
\end{abstract}

Keywords: design intervention; pedestrian street; heritage site; conservation; street vendor

\section{Introduction}

Kuala Lumpur, a city that was born from a humble beginning in the early 1880s, is fast becoming a global city and a tourism capital. In its early days, there were at least seven recorded traditional Malay settlements located around where Kampong Baru is today [1]. Most of the villagers were farmers whose life depended on cultivating their food. It was only about a decade later when an influx of Chinese immigrants was brought into Kuala Lumpur to work for the tin mining industry, which truly changed Kuala Lumpur's landscape forever. The immigrants, a few of which were from wealthy families, and traders built a small town, serving their communities and providing a place where people from various backgrounds could obtain needed goods. Today, it is an area that locals and foreign tourists call "Chinatown," especially Petaling Street, which has been a permanent pedestrian street ever since [2]. In 2003, Petaling Street underwent a significant facelift. It became the first covered pedestrian street in Kuala Lumpur, which was later followed by a similar project in Jalan Masjid India and Jalan Hang Kasturi. Jalan Hang Jebat was later commercially renamed to "Kasturi Walk." This effort is 
believed to have been done without any professional consultation, thus invoking a debate regarding its many pros and cons. Knowing that the structures were erected in Kuala Lumpur's historical enclave, there is an argument that this will further contribute to losing the heritage ambience of the old part of Kuala Lumpur [3].

\section{Literature Review}

\subsection{Kuala Lumpur Heritage Area and Challenges}

The reason for the challenges regarding the heritage areas in Kuala Lumpur is that these areas had been damaged for so long by poor planning decisions and insensitive developments [4]. Kuala Lumpur City Hall should have acted as a custodian of Kuala Lumpur's heritage and carried the responsibly to safeguard, strengthen, and enhance the remaining heritage areas for the sake of the city's identity and to maintain a source of pride for its citizens. ICOMOS (International Council on Monuments and Sites) Malaysia has voiced serious concerns over the lack of emphasis on the heritage conservation agenda in the recently announced "Draft Kuala Lumpur Structure Plan 2040 (DKLSP2040)" [5]. The review committee of the DKLSP2040 from ICOMOS Malaysia, whose members are architects, landscape architects, heritage conservators, and urban planners, laments:

Heritage protection is not against development - it can go hand in hand rather successfully if plans are conceived with heritage in mind. We want a city that could recognise itself developed not at the expense of our historic chronology and a better quality of life. As the guardian of Kuala Lumpur's history and heritage, Kuala Lumpur City Hall must make obvious attempts to safeguard the city's heritage assets. Unless a focus is placed on heritage matters transparently, the 'City for All' will end up just another conceptual slogan and what lies ahead would be the same problems and issues we have yet to solve [4].

Therefore, alongside the Sustainable Development Goals presented by the United Nations, which call for "strengthening efforts to protect and safeguard the world's cultural and natural heritage" [6], ICOMOS Malaysia calls for the city hall to adopt recommendations from the New Urban Agenda (NUA), as discussed in the following:

Clause 125: We will support the leveraging of cultural heritage for sustainable urban development and recognize its role in stimulating participation and responsibility. We will promote innovative and sustainable use of architectural monuments and sites, with the intention of value creation, through respectful restoration and adaptation. We will engage indigenous peoples and local communities in the promotion and dissemination of knowledge of tangible and intangible cultural heritage and protection of traditional expressions and languages, including through the use of new technologies and techniques [7].

These intentions are supported by claims in other sections that are related to urban heritage conservation, such as in Clauses 32,38,60, and 94. All these recommendations were put forward to safeguard the identity of a city, its culture, and its history, with a long-term goal to create a sustainable city for all. As such, it is important to ask: what is the identity of Kuala Lumpur? Historically, ubiquitous street activities surrounded by vernacular shophouse architecture and its uniformity, street hawkers, peddlers, overcrowded streets, and rickshaws are all part of a common image of the old Malayan town from the yesteryears, including Singapore. According to Savage [8], a city, in those days, was characterized by its atmosphere, noise, and smells. Kuala Lumpur shares a lot of similar characteristics with Singapore, although the latter was historically more significant. In a city like Kuala Lumpur, bustling business and commercial activities have often exerted pressure for land parcels within its vicinity to be developed and re-developed. In developing Asian countries, historical districts have suffered, due to the unavailability of transparent and prudent laws and guidelines [9]. Shuhana et al. [3] have pointed out that the decline of the heritage environment was due to the absence of effective legal protection and a lack 
of control within the local government. They also related this problem with modernization and economic interest regarding replacing old shophouses with new buildings, which can give better profits. Furthermore, a lack of funding and financial benefits from the building owners and tenants themselves eventually contributed to the dilapidated condition of the historical enclave. Another issue that threatens the heritage area in Kuala Lumpur is the lack of enforcement of an "allowable height limit" for new buildings in the heritage area. According to the Draft Kuala Lumpur City Plan 2020 [10], the allowable heights for all areas are guided by the General Allowable Height Plan (GAHP), which serves as a guide for any new developments within Kuala Lumpur, including in heritage areas. A new development is allowed, as long as it does not exceed the allowable plot ratio and the maximum allowable height indicated in the GAHP; in the heritage area, the allowable height is at most 30 stories (120 m). Interestingly, a new tallest tower in Kuala Lumpur named "PNB 118," which is currently under construction, has 118 stories, with a total height of $644 \mathrm{~m}$ (five times the height limit); this tower has invoked fierce criticism from the public [11]. While it is widely understood that conservation involves "managing change" in a significant heritage area, this involves sustaining the area's natural and cultural heritage values, while recognizing opportunities to elevate and enhance the values for present and future generations [12]. By looking at the current situation, it can be seen that the conservation of this heritage area in Kuala Lumpur is indeed a huge challenge.

\subsection{Design Intervention in the Heritage Area}

According to the New Design in Historical Settings, a guideline issued by Historic Scotland, a special agency set up by the Scottish Government, the historic setting is a natural or designed space that encompasses the setting up of individual or set-piece heritage complexes around buildings and monuments, conservation areas or landscape design [13]. This guideline also states that there are many aspects of successful historic sites that cannot be easily measured, for example, by their architectural features. The intervention or any introduction of new elements, mostly new buildings or structures, will always call for arguments. According to Historic Scotland, the addition of a newly designed structure helps to enhance the character of the historic place and also helps to realize its full economic and cultural potential. Therefore, the old area survives naturally. In other words, it survives without any 'forced elements,' particularly by an authority, as can be seen in Singapore. The guideline also states that the success of the introduction of a modern structure relies on the appointment of a designer with the appropriate design and analytical skills and the relevant experience at the beginning of the project, the preservation of the quality of the heritage building and the respect for the existing one. Additions to heritage buildings are one of the most important issues in the field of architectural conservation, as there are many discussions on the correct approach to new additions in the historical context [14]. Warren [15], on the other hand, points out that intervention that is vigorously new and disruptive may reduce the quality of the historical environment. The intervention, he adds, must be determined by the interaction of three polarities; the community; the owner; the designer. He believes that the designer should be aware of historical circumstances and have a sense of responsibility for historical evidence. Designer as an artist, he says, has a personal and self-interest in expressing their artistic views. However, in the historical context, designers with a sensitivity to the quality or taste of the historic environment will find themselves taking special care of the impact of their work. It suggests that any intervention must: i) use the style of architecture that is appropriate for place and time, ii) volume and massing must be maintain harmony with the established forms, iii) color, scale and texture must be comparable to the historic environment, and iv) use of the insertion that must not interfere with the context established. These, according to Warren [15], may 'soften' the impact of the insertion —or what he refers to as 'amelioration', make something bad or damaged better. At the same time, Turner [16] suggests that three principles should guide planners when discussing intervention in historical contexts; i) knowledge of the past, ii) understanding of the present, and iii) vision of the future. Furthermore, he describes that any intervention must respond to three things: when, how, and what. Heritage Enclaves that have suffered so much damage to their context can never be 
conserved on their own. Intervention, according to Turner [16], should take place where there are both positive and negative impacts on public goods. It should also be guided by a combination of sound zoning and environmental impact procedures. This is how the intervention should be carried out. Finally, intervention should lead to a better relationship and link between the context, the environment and development. Dennis [17], in his article on the integration of modern architecture, says that there are two groups of practitioners, the first of whom are the designers of one-off buildings, who advocate a policy of contrast between new and old with the use of new and modern materials, while the second group supports the conservationist 'blenders and melders,' an architectural design that resembles or mimics the past. Dennis [17], however, agrees with the idea of letting market forces and designers know how to intervene. To him, a new urban richness through 'city regeneration' as Singapore has done can create a new urban space that is connective, flexible and dynamic. It is indeed the responsibility of the designers to combine the old with the new by a 'sensitive modern addition'. Looking at the covered pedestrian street project in Petaling Street, planned and executed by the Authority, Shuhana et al. [3] describes that it is merely an upgrade project and that it is not qualified for conservation simply because the project has not undergone any phases that should be undertaken for conservation. It is only an improvement project that provides shelter for shoppers and visitors from extreme tropical weather that causes the façade of shophouses to be hidden. Furthermore, in the context of Malaysia's historical context, the authors argue that the political agenda is likely to be the main contribution to the changes resulting from the demand for tourism and the economic factor. By focusing heavily on tourism, they questioned that the essence of shopping in an open area is now completely lost. In the past, as in other traditional markets, Petaling Street was occupied by multi-colored umbrellas and impermanent stalls selling daily food. The authors believe that the authenticity of the historical enclave, which was described as 'atmosphere originally built into the building', is replaced by a new intervention, which is purely tourism oriented.

When the Singaporean Government launched a conservation program through the Urban Redevelopment Authority, or rather called 'urban revitalization,' in 1971, a pilot project in which state-owned shophouses were chosen as a demonstration of the approach, method and technique of shophouse restoration. The Singaporean Government is aware that conservation involves a large amount of budget. Later, the private sector was invited to participate in conservation activities through the Sale of Sites program [18]. This was another initiative of the Singaporean authority, where a conserved set of buildings was returned to the private sector for renovation (adaptive re-use, according to the commercial nature of the new owner). Although construction conservation in Singapore has begun since the early 1970s, it is only in 1986 that a massive conservation program was launched as the number of tourists began to decline [19]. Later, as the Singaporean Government intended for more privately initiated conservation, the word 'conservation' has become a popular marketing strategy for tourism and commercial-based businesses in particular. According to Teh [18], currently about $80 \%$ of the conserved buildings in Singapore are privately owned. As a priority for monetary profits, these private companies are seeking a more relaxed and flexible conservation guideline. The phrase 'old and new integrated development' has been included in Singapore's conservation programme, as economic viability and profit are seen as the main priority. Examples are as we can see in Far East Square, Clarke Quay and Bugis Junction; this 'attractive and interesting space' has successfully turned Heritage Enclaves into Singapore's tourist attraction. Not because they value heritage buildings and their history, but as a place where they can shop and dine in a sterile and air-conditioned atmosphere. The buildings are there, but the heritage is gone. 'Design Flexibility,' as described by Teh [18], enables developers to adapt historic enclaves to the theme set by their own business ambitions. Furthermore, Savage [11] is questioning what is known as 'conservation' in Singapore, saying that conservation is not just about buildings and structures, but the street life that is disappearing in Singapore is the essence of what Heritage Enclaves are known in its yesteryears. He suggested that the restoration of shophouses is not sufficient, but the preservation of the street culture; by means of its street activities, such as Passa Malam (traditional night market), must be maintained. The area with only tourist-oriented shops 
will lose its local and cultural atmosphere. Savage [11] shared a similar view with Shuhana et al. [3] that changing the context of urban heritage into something that favors over-market tourism is very detrimental to the authenticity and sustainability of heritage sites.

\section{Objectives and Methodology}

The aim is to explain and illustrate the way this study has been carried out. Theoretical sampling was used in this study, where focus groups were identified, and for each group with different backgrounds and characters, a different type of interview was conducted [20]. This objective sampling practice allows the selection of information and exploratory data to be collected from respondents and informed participants who have had active participation in the heritage area. This study wishes to analyze the opinions of 3 focus groups who are directly and indirectly involved in the subject matter, as shown in Table 1:

1. Group A: Traders and business owners in heritage area (Petaling Street, $R(A) 1$ to $R(A) 10$, and Kasturi Walk, R(A)11 to R(A)17)

2. Group B: Officers in Kuala Lumpur City Hall

3. Group C: Professionals

Table 1. Respondents' profile.

\begin{tabular}{|c|c|c|c|c|}
\hline $\begin{array}{l}\text { Respondent } \\
\text { (Group) }\end{array}$ & Gender & Age & Role/Occupation & Interview Method \\
\hline $\mathrm{R}(\mathrm{A}) 1$ & $\mathrm{~F}$ & $40-50$ & Plastic houseware seller & \multirow{17}{*}{$\begin{array}{l}\text { Face-to face, survey } \\
\text { interview (open-ended } \\
\text { unstructured) }\end{array}$} \\
\hline $\mathrm{R}(\mathrm{A}) 2$ & $\mathrm{~F}$ & $40-50$ & Roasted meat peddler & \\
\hline $\mathrm{R}(\mathrm{A}) 3$ & $\mathrm{~F}$ & $30-40$ & Florist & \\
\hline $\mathrm{R}(\mathrm{A}) 4$ & M & $50-60$ & Dried fruit seller & \\
\hline $\mathrm{R}(\mathrm{A}) 5$ & $\mathrm{~F}$ & $40-50$ & Fresh fruit seller & \\
\hline $\mathrm{R}(\mathrm{A}) 6$ & M & $50-60$ & Fresh fruit seller & \\
\hline $\mathrm{R}(\mathrm{A}) 7$ & M & $50-60$ & Souvenir shop owner & \\
\hline $\mathrm{R}(\mathrm{A}) 8$ & $\mathrm{~F}$ & $50-60$ & Souvenir shop owner & \\
\hline $\mathrm{R}(\mathrm{A}) 9$ & M & $30-40$ & T-shirt seller & \\
\hline $\mathrm{R}(\mathrm{A}) 10$ & $\mathrm{~F}$ & $40-50$ & Herbal tea shopkeeper & \\
\hline $\mathrm{R}(\mathrm{A}) 11$ & $\mathrm{~F}$ & $30-40$ & Phone accessories seller & \\
\hline $\mathrm{R}(\mathrm{A}) 12$ & M & $50-60$ & Batik shop owner & \\
\hline $\mathrm{R}(\mathrm{A}) 13$ & $\mathrm{~F}$ & $20-30$ & Souvenir shop owner & \\
\hline $\mathrm{R}(\mathrm{A}) 14$ & M & $30-40$ & Souvenir shop owner & \\
\hline $\mathrm{R}(\mathrm{A}) 15$ & M & $30-40$ & Souvenir shop seller & \\
\hline $\mathrm{R}(\mathrm{A}) 16$ & $\mathrm{~F}$ & $20-30$ & Fruit juice shopkeeper & \\
\hline $\mathrm{R}(\mathrm{A}) 17$ & $\mathrm{~F}$ & $30-40$ & Traditional sweets seller & \\
\hline $\mathrm{R}(\mathrm{B}) 1$ & $\mathrm{~F}$ & $20-30$ & City Hall Officer & \multirow{2}{*}{$\begin{array}{l}\text { In-depth interview } \\
\text { (open-ended structured) }\end{array}$} \\
\hline $\mathrm{R}(\mathrm{B}) 2$ & $\mathrm{~F}$ & $20-30$ & City Hall Officer & \\
\hline $\mathrm{R}(\mathrm{C}) 1$ & M & $30-40$ & Architect/Academician & \multirow{12}{*}{$\begin{array}{c}\text { Expert opinions } \\
\text { (open-ended unstructured) }\end{array}$} \\
\hline $\mathrm{R}(\mathrm{C}) 2$ & M & $30-40$ & Architect/Academician & \\
\hline $\mathrm{R}(\mathrm{C}) 3$ & M & $40-50$ & Architect/Academician & \\
\hline $\mathrm{R}(\mathrm{C}) 4$ & M & $40-50$ & Architect/Academician & \\
\hline $\mathrm{R}(\mathrm{C}) 5$ & $\mathrm{~F}$ & $40-50$ & Architect/Academician & \\
\hline $\mathrm{R}(\mathrm{C}) 6$ & $\mathrm{~F}$ & $30-40$ & Architect/Conservator & \\
\hline $\mathrm{R}(\mathrm{C}) 7$ & M & $40-50$ & Architect/Conservator & \\
\hline $\mathrm{R}(\mathrm{C}) 8$ & M & $70-80$ & Architect & \\
\hline $\mathrm{R}(\mathrm{C}) 9$ & $\mathrm{~F}$ & $50-60$ & Architect & \\
\hline $\mathrm{R}(\mathrm{C}) 10$ & M & $30-40$ & Urban Planner & \\
\hline $\mathrm{R}(\mathrm{C}) 11$ & M & $30-40$ & Urban Planner & \\
\hline $\mathrm{R}(\mathrm{C}) 12$ & M & $30-40$ & Structure Engineer & \\
\hline
\end{tabular}


This method of study on the covered pedestrian street was chosen because there were many critics from professionals [3], in particular among heritage conservationists, who argued that the roofing structure erected by the authority could harm the authenticity of the Heritage Enclaves in Kuala Lumpur. The interviews were conducted in two different ways, structured and unstructured. Three different groups of respondents were involved in meeting the objectives of this paper. The first group (A) is made up of traders in the case study areas who are not only familiar with, but are directly involved in, the situation. This group was also selected as part of the government sector, which is assumed to understand more about conservation issues and government regulations. Moreover, the last group, the third group $(\mathrm{C})$, is made up of professionals who are practicing, independent, unrelated to any government sector or authority. This may ensure that their opinion is non-biased. They will therefore not only express their opinion on the design factor, but also on other important points relating to the subject.

A structured in-depth interview was conducted specifically for the group B respondents. This includes specific points as set out in Table 2; i) the role of Heritage Unit, Kuala Lumpur City Hall, (ii) how the Authority designates Heritage Enclaves in Kuala Lumpur, (iii) the procedure for intervention in the Heritage Enclave, (iv) response by stakeholders before and after the project, and (v) availability of the guidelines for Kuala Lumpur Heritage Enclave. These questions were addressed to officers from the Kuala Lumpur City Hall who were willing to share their knowledge of how Kuala Lumpur's governing body deals with the Heritage Enclave. One officer is serving the Heritage Unit under the Urban Design and Building Department, and another officer is from the Urban Planning Unit. They were selected as directly involved in some of the projects in the Kuala Lumpur Heritage Enclave. During the interview, other supporting questions were also raised. The questions were designed to provide an overview of the structure of the City Hall and how the City Hall manages the heritage area of Kuala Lumpur.

Table 2. Qualitative research question for Group B.

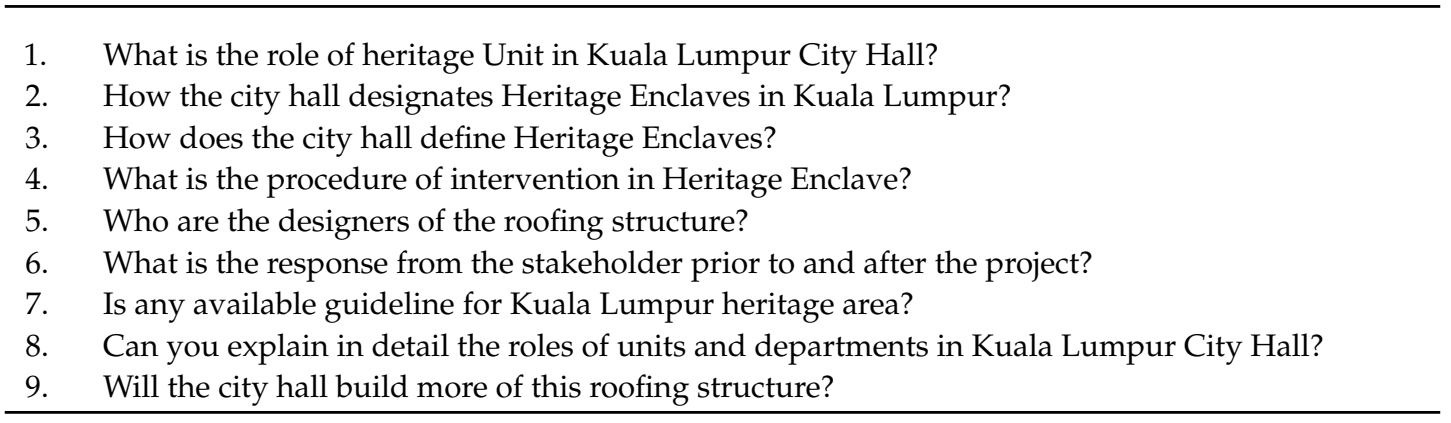

Open-ended questions are exploratory, giving richer, more qualitative data [21]. Essentially, it provides a wider opportunity to gain more insight into the specific subject. Another way to interview was an unstructured interview in the form of a less formal conversation with selected traders in the case study areas. Traders were chosen at random from the different nature of the business. This may give a personal view of those directly affected by the pedestrian street projects in question. Their insight opinions are important in finding out what are the real issues that the authority should take into account in similar projects in the future. Ten traders in Petaling Street and 7 from the recently built Kasturi Walk were selected for this research. They were chosen on the basis of their willingness to have a conversation. The informal, unstructured, open-ended interview was conducted as they were unfamiliar with formal academic research. This method is thought to be more friendly and able to obtain more and more information beyond the research subject compared to a pre-designed close-ended interview. A personal face-to-face survey interview is typically used when a specific target group is involved. However, being an open-ended face-to-face method, interviewing 17 people took a longer time to collect data. However, the issues raised during the conversation relate to the following topics: i) years of operation of the trader, (ii) involvement of the 
community, (iii) opinion on roofing structures and other related issues. However, a similar approach to Group B was taken by expert opinions, with more questions being asked more seriously.

Respondents from different groups A, B and C also showed a comparative photo of Petaling Street and Jalan Hang Kasturi before and after the roofing was erected and either of which they preferred the most (Figures 1 and 2). This method is intended to exercise their opinion on the basis of the real condition of the street, as most of the respondents experienced the site before the original ambience of the covered pedestrian project had changed. This method can give respondents a true picture of what Petaling Street was; a very traditional way of doing business that was said to be more 'authentic', as Shuhana et al. argued [3]. They were given the option to choose Photo A (case study with roof structure) or Photo B (case study prior to the roof installation), as shown in Figures 1 and 2.

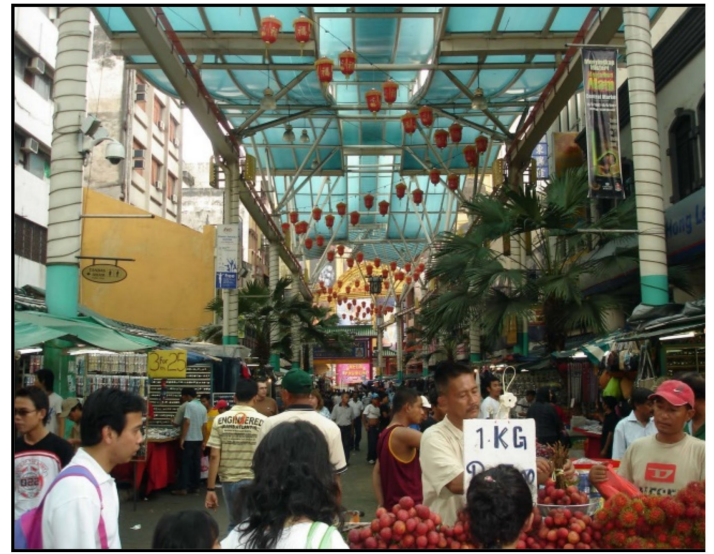

(a) After the roofing structure was erected

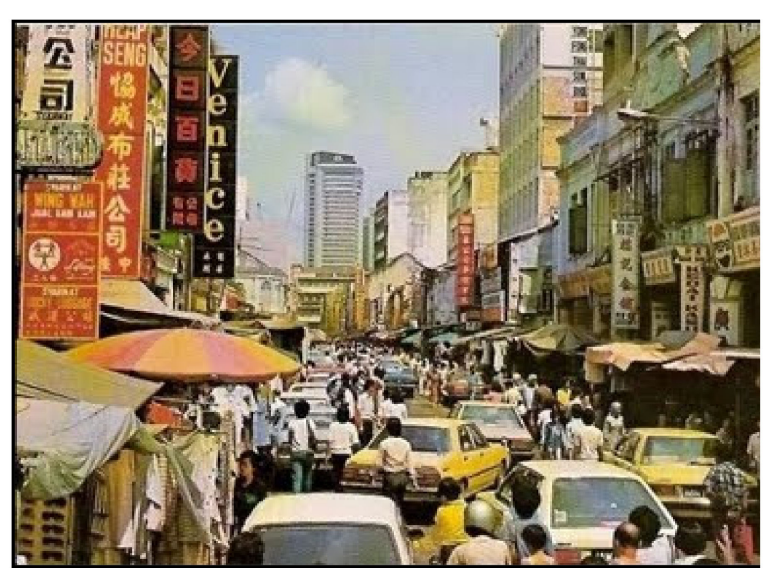

(b) Before the roofing structure was erected

Figure 1. Petaling Street after and before the covered pedestrian street project. (a) The street covered with blue colored roofing with aligned palm trees planted for aesthetic purpose. Red lantern also can be seen in the photo as to express the 'Chinese-ness' of Petaling Street. (b) Umbrellas and congested traffic were part of the scenario of Petaling Street. There were also vertical signages that bring more colors to the street.

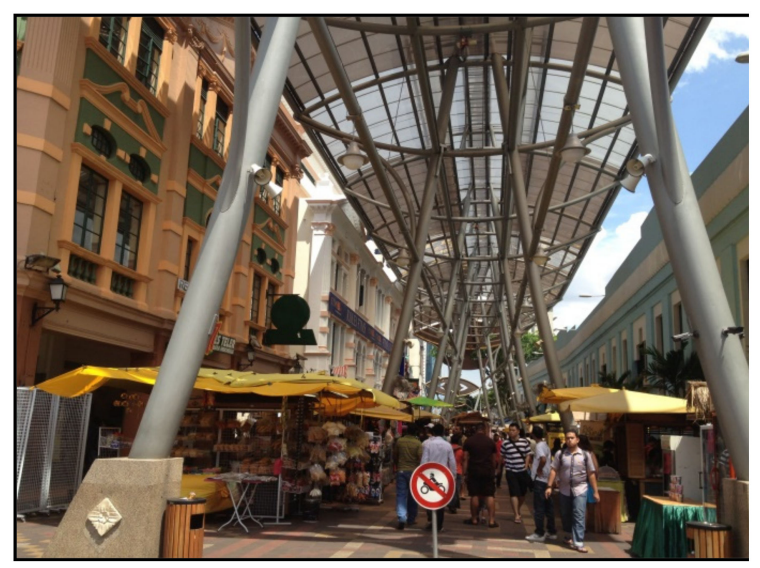

(a) After the roofing structure was erected

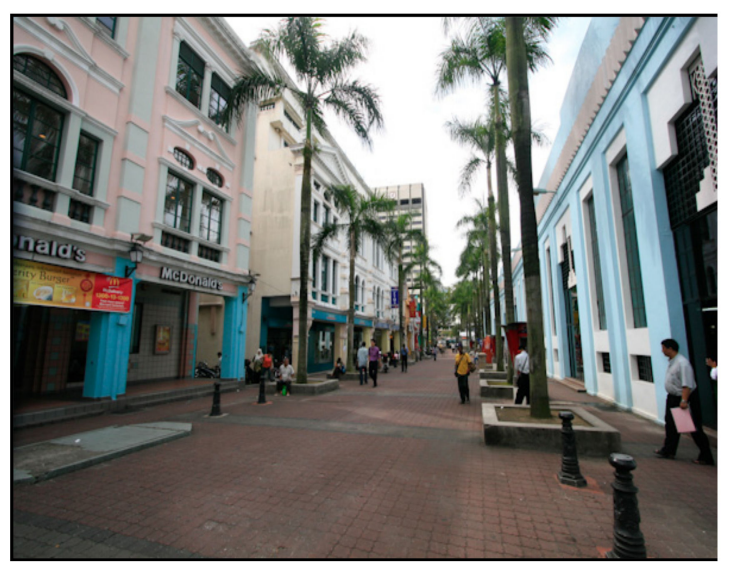

(b) Before the roofing structure was erected

Figure 2. Jalan Hang Kasturi, after and before the covered pedestrian street project. (a) After the erection of the covered pedestrian walkway, the once empty street of Jalan Hang Kasturi. (b) Turned into a street market and renamed as "Kasturi Walk'.

\section{Results and Discussion}

In this section, two historical areas of Kuala Lumpur which had experienced a permanent intervention through the installation of the roofing structure will be analyzed. For each case study, five themes are discussed on the basis of the questions asked to the respondents from Group B; 
(i) The role of the heritage unit in the determination of heritage areas, and (ii) the procedure of intervention in the Heritage Enclave, (iii) the designers behind the roofing structures, (vi) the response from the stakeholder prior and after the project, and (v) availability of guideline for Kuala Lumpur Heritage Enclave.

In order to obtain information from the authority on how the covered pedestrian street projects were carried out, a face-to-face, individual structured interview with officials from the Department of Urban Design and Building, Kuala Lumpur City Hall, was organized. The results of a discussion with the Kuala Lumpur City Hall officials on how the beautification programs were carried out and implemented in the Kuala Lumpur Heritage Enclaves have come out with this interesting input. Generally, the Kuala Lumpur City Hall uses two methods of decision-making in project planning; the top-down method and the bottom-up method. There are no clear guidelines or explanations as to which method the local authority prefers the most, but normally the top-down approach is preferred when the Mayor himself instructs the project on the basis of his own idea. Respondents argued that there is still no guideline for the conservation of heritage buildings in Kuala Lumpur. The Kuala Lumpur Heritage Enclaves Heritage Conservation Program has not yet been planned, and the beautification project cannot be considered as a conservation project. At the same time, however, they pointed out that the roofing structure in Petaling Street and Kasturi Walk was designed by the Department of Architecture without a fully covered roofing structure, which is related to the local authority requirement of the Uniform Building By-Law (UBBL) 1984, that the local authority should provide mechanical ventilation, which is too costly. Finally, for the time being, there is no plan to introduce another covered pedestrian street project in Kuala Lumpur.

In the top-down approach, the highest official or top-level management level, or sometimes the politician, is the one who gives orders or instructions to lower-level officials to follow or execute (Figure 3). In Kuala Lumpur City Hall, in many recent beautification projects, the Mayor gives his idea or direction for the authority to work. Table 3 shows the role of Kuala Lumpur City Hall departments in beautification projects. In this case, the Mayor either gives his direction to the Department of Urban Design and Building or to the Department of Architecture to come up with a design or a plan to embellish or upgrade certain areas of the city, which are generally in a forgotten or down-to-earth situation. If it is given to the Department of Urban Design and Building, it must go through the Master Plan Department, where the Department has a comprehensive master plan, the Kuala Lumpur Structure Plan 2020, which acts as a guiding document for urban planning. The Department of Architects does not need to go through the Department of Master Plans. The cost of the project will be allocated to the Finance Department at a later date. It will either go back to the Department of Urban Design and Building or to the Department of Architecture to obtain its final approval from the Mayor, if not the Director General. This approach is usually implemented for a specific project that requires immediate action. Most Kuala Lumpur beautification projects are carried out using this method. However, the involvement of the various departments within the Kuala Lumpur City Hall is necessary in order to obtain a consensus and valuable input from other departments, in particular the Department of Urban Transport and Public Works.

On the other hand, bottom-up is the normal procedure for any well-managed organization. It works on specific departmental plans and implements its program. Usually, this approach is used for minor and routine programs. The Kuala Lumpur City Hall starts with either the Urban Design and Building Department or the Architects Department proposing its program (Figure 4). Its estimated costs will be assessed by the Department of Quantity Survey. For the Department of Urban Design and Building, it has to go through the Department of Master Plan for confirmation, as it involves the city's structural plan. The Department of Finance will then approve the request for allocation in accordance with the budget allocated to that department. Finally, the Deputy Director-General or the Director-General shall authorize the execution of the project at the agreed cost. This approach, similar to the top-down approach, requires an inter-departmental discussion in order to obtain a standard view and input from all departments directly or indirectly involved in the project area. 


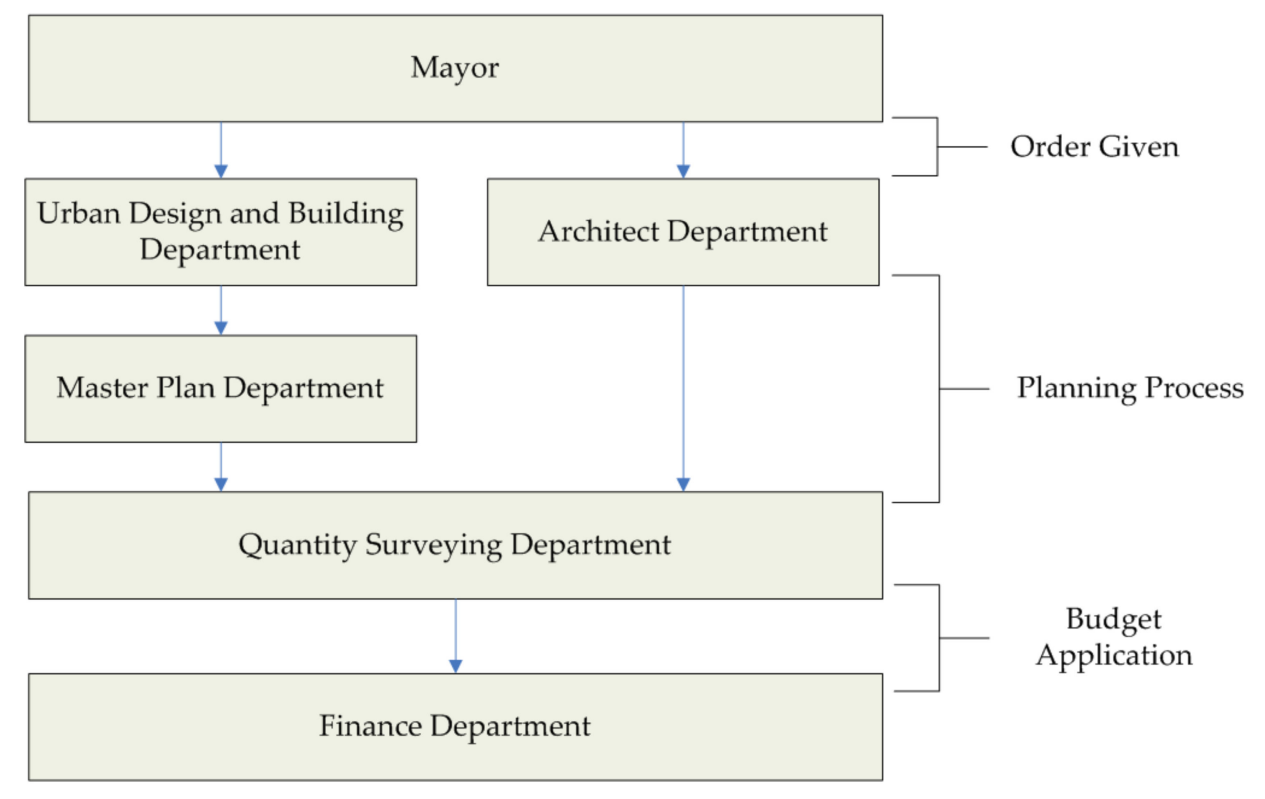

Figure 3. Top-down approach in the designing project in Kuala Lumpur Heritage Enclaves.

Table 3. Function of the Kuala Lumpur City Hall's departments in beautification projects.

\begin{tabular}{|c|c|c|}
\hline No. & Department & Functions (Related to Conservation and Beautification Project) \\
\hline 1 & Architect Department & $\begin{array}{l}\text { - Plans, designs and manages the construction of buildings and } \\
\text { public-facility projects. } \\
\text { Provides technical services in construction, civil, and structural } \\
\text { to other departments of the Kuala Lumpur City Hall. }\end{array}$ \\
\hline 2 & $\begin{array}{l}\text { Urban Design and } \\
\text { Building Department }\end{array}$ & $\begin{array}{l}\text { - Process applications and issue approval for design and } \\
\text { building plans. } \\
\text { - Conduct planning research, planning guidelines and } \\
\text { regulations for short and long term urban design, architecture, } \\
\text { heritage sites and buildings } \\
\text { - Implementing beautification projects, identifying, monitoring } \\
\text { and upgrading old and dilapidated areas }\end{array}$ \\
\hline 3 & Master Plan Department & $\begin{array}{l}\text { - Responsible for the physical development planning of } \\
\text { Kuala Lumpur } \\
\text { - } \\
\text { Monitor and guide land development activities to be in line } \\
\text { with the adopted development plans }\end{array}$ \\
\hline 4 & $\begin{array}{l}\text { Quantity Surveying } \\
\text { Department }\end{array}$ & $\begin{array}{l}\text { - } \quad \text { Provide cost management and privatization contracts } \\
\text { - Provides quantity surveying services at the pre-contract and } \\
\text { post-contract stages }\end{array}$ \\
\hline 5 & $\begin{array}{l}\text { Public Works } \\
\text { Department }\end{array}$ & $\begin{array}{l}\text { - Upgrade and increase the capacity of existing roads } \\
\text { - } \quad \text { Improve drainage footpath networks }\end{array}$ \\
\hline 6 & Finance Department & $\begin{array}{l}\text { - } \quad \text { Prepare annual budget } \\
\text { - } \quad \text { Member of the Implementation of Special Projects and } \\
\text { privatization under Kuala Lumpur City Hall }\end{array}$ \\
\hline 7 & $\begin{array}{l}\text { Urban Transportation } \\
\text { Department }\end{array}$ & $\begin{array}{l}\text { Manage and maintain the operations of the public } \\
\text { parking system }\end{array}$ \\
\hline
\end{tabular}

As in Table 4, ten (10) different traders in Petaling Street were approached and interviewed, in order to obtain their opinion on issues related to the roof structure. Meanwhile only seven (7) Kasturi Walk traders managed to be interviewed for this study (Table 1). A roasted meat peddler has inherited the business from her father, who has been in business for almost 50 years. Almost the same thing 
for the dry fruit seller, he's been running the business for the same period since his father. The florist, on the other hand, began the flower business almost 15 years ago. When asked about the effect of the roofing structure on the nature of their business, all the respondents agreed that it had no effect on their business. The roasted meat peddlers, however, said that the roofing could not provide enough shelter from the rain, but at the same time agreed that the roofing structure should be there. On the other hand, the florist did not agree with the pedestrian project, as she said it would only block the movement of trucks for loading and unloading goods. Talking about the problems affecting their business, the roasted meat peddlers said that the lack of car parking facilities is the leading cause that reduces the number of local visitors, their regular customers. Many other respondents also raised the issue of parking limitation. Respondents also expressed concern about the lack of local residents living and visiting the area as they used to be. The area is now mostly populated by foreign workers and foreign tourists, who had no historical or emotional connection to the area.

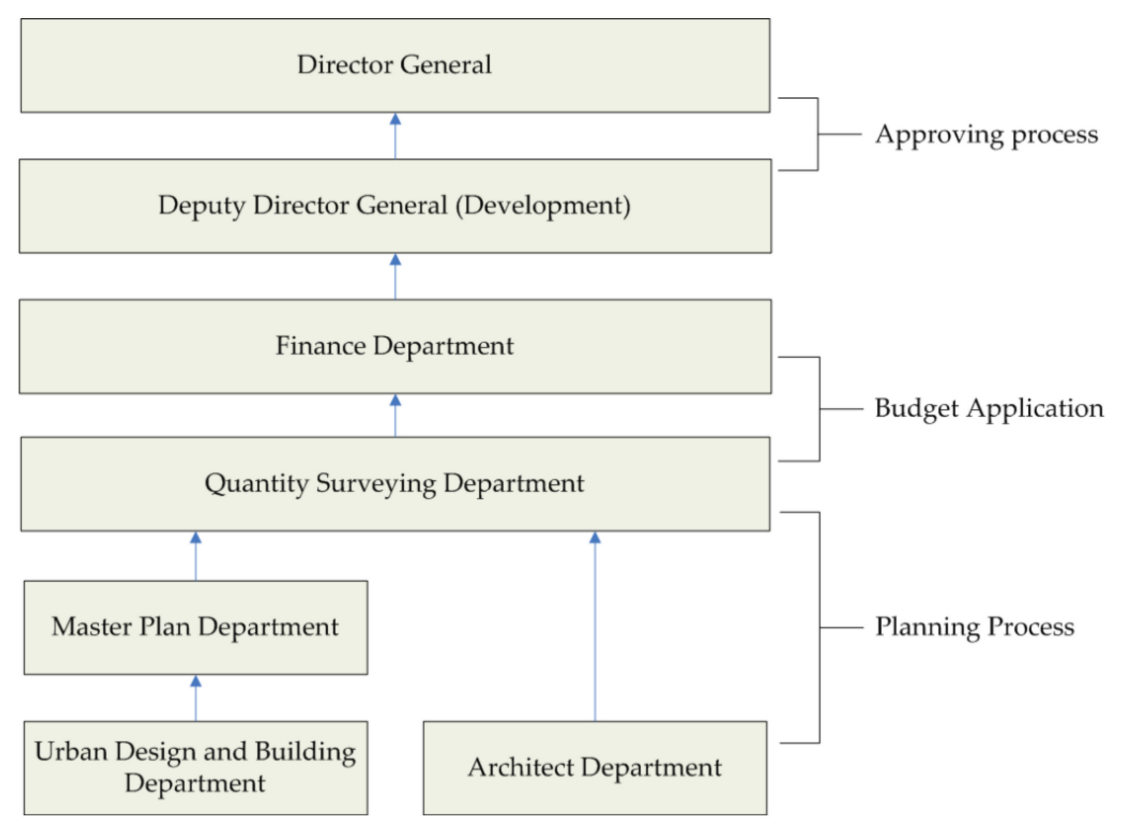

Figure 4. Bottom-up approach in designing project in Kuala Lumpur Heritage Enclaves.

In Kasturi Walk, seven business owners were interviewed in order to get their perception of the covered pedestrian street project. A batik designer and seller, who said he has had a business in the Central Market since 1988, applauds the Kasturi Walk project, as he said it was an extension of the Central Market itself. He managed to get three kiosks in the Kasturi Walk, selling the same tourist-oriented products he has in the Central Market. The only problem he pointed out was the rain splash, as the design of the Kasturi Walk did not fully cover the street. Another business owner, the owner of a souvenir shop, said that she was one of the pioneers of the restored Central Market, which was once a wet market, until it became a cultural market in 1984. She said that the covered pedestrian street does not affect her business inside the Central Market, as it is air-conditioned compared to the Kasturi Walk. She said that shoppers prefer air-conditioned malls rather than open-air street malls, as Kuala Lumpur has unpleasant weather most of the time. However, she also rented a booth in Kasturi Walk and hired an employee to keep the shop. However, problems such as lack of parking space and competition from other business centers are threatening her business, the same problem faced by paddlers in Petaling Street; in addition, rising rental fees are another problem she has to face. From an interview with traders in both case study areas, the summaries are i) traders have no objection to the roofing structure. In fact, they welcome the initiative, ii) the only problem with the roof is that it cannot provide full protection from rain splash, iii) traders complain about the lack of car parking facilities, which could be one of the reasons why heritage areas are losing their regular 
customers. Last but not least, traders on both Petaling Street and Kasturi Walk do not seem to be really concerned about the heritage value of the site, and their business survival is more relevant to them than the conservation of the heritage area. This is completely contradictory with the answers given by Group $C$, the professionals. The main concern of Group $C$ is the value of the heritage of the site. They lamented the design of the roofing structure that they thought was unsuitable for the place, and the cheap polycarbonate that made up the roof makes it look very unpleasant. They called on the local authority to conduct a design competition, so that only the best design with good aesthetics can be built. The professional group also asked for at least the façade to be renovated, in order to preserve the heritage ambience of Petaling Street. There are a few old storehouses that have been blocked by the structure and left decayed. Group $C$ also seeks clarity from the local authority on the process and procedure for safeguarding heritage areas such as Petaling Street, in such a way that it will have a better image among visitors rather than just a place to buy counterfeit products made in China. The historic pedestrian streets of Kuala Lumpur must be built as a place to showcase Malaysian history and culture, and not just as another place to sell another generic item. Finally, Group C requested that, if there is any new pedestrian street ever built in the heritage area, activities promoting the culture and uniqueness of Kuala Lumpur should be carried out.

Table 4. Respondents' opinions on the historical pedestrian streets.

\begin{tabular}{|c|c|c|}
\hline Respondents & Narrative Theme & Quotations \\
\hline \multirow{8}{*}{ Group A } & $\begin{array}{l}\text { The roof structure is } \\
\text { helpful }\end{array}$ & $\begin{array}{l}\text { - The roof can provide shelter from the hot sun in the afternoon } \\
\text { but does not really provide shelter during heavy rain. } \\
\text { Rain splash makes the roof looks useless but thankful for the } \\
\text { protection from the sun. }\end{array}$ \\
\hline & $\begin{array}{l}\text { The business routine } \\
\text { does not change }\end{array}$ & $\begin{array}{l}\text { - The roof does not affect the business. The roof structure does } \\
\text { not influence the business routine but helpful to visitors. } \\
\text { - Daily rain pours in Kuala Lumpur makes the roofing necessary. }\end{array}$ \\
\hline & $\begin{array}{l}\text { Does not aware of the } \\
\text { design process }\end{array}$ & $\begin{array}{l}\text { - Have no idea who and how they make the roofing structure. } \\
\text { - Never get consulted but suspect the association already knew } \\
\text { and the association's input was already taken. }\end{array}$ \\
\hline & $\begin{array}{l}\text { The decreasing number } \\
\text { of Chinatown residents }\end{array}$ & $\begin{array}{l}\text { - Local residents no longer living in Chinatown. Only foreign } \\
\text { - } \quad \text { Loskers and surrounding hotel guests are the 'residents' } \\
\text { away from Chinatown. } \\
\text { - Tourist only visits and take photo and not really buying. } \\
\text { - Most customers are local Malaysians and their numbers as a } \\
\text { visitor are decreasing. }\end{array}$ \\
\hline & Lack of parking & $\begin{array}{l}\text { - Complaints from regular customers that parking in Chinatown } \\
\text { area is hard to find therefore reluctant to come. } \\
\text { Loading and unloading become troublesome. Prefer the street } \\
\text { not to be fully pedestrianized for the purpose of loading } \\
\text { and unloading. } \\
\text { Expensive parking. }\end{array}$ \\
\hline & Competition & $\begin{array}{l}\text { - Supermarkets and convenience stores nearby are a threat to } \\
\text { business survival. } \\
\text { - } \quad \text { Cannot compete with the price offered by supermarkets. }\end{array}$ \\
\hline & Rental against profit & $\begin{array}{l}\text { - Kasturi Walk is private-owned, and rental is not cheap. } \\
\text { - Competition with many similar businesses means lower } \\
\text { profit margin. }\end{array}$ \\
\hline & $\begin{array}{l}\text { The lack of cultural and } \\
\text { heritage awareness }\end{array}$ & $\begin{array}{l}\text { - } \quad \text { Business survival is more important than heritage buildings. } \\
\text { - } \quad \text { Doesn't think the roofing is threatening the heritage ambience. }\end{array}$ \\
\hline
\end{tabular}


Table 4. Cont.

\begin{tabular}{|c|c|c|}
\hline Respondents & Narrative Theme & Quotations \\
\hline \multirow{5}{*}{ Group C } & Design a lack of esthetic & $\begin{array}{l}\text { - The design does not respect the heritage environment. } \\
\text { - Cheap material makes the design even worse. Polycarbonate } \\
\text { roofing is unpleasing to see. } \\
\text { - Roofing defeats the purpose of giving shelter during rain. } \\
\text { Design competition should be done in order to get the best } \\
\text { design options. }\end{array}$ \\
\hline & Over-tourism & $\begin{array}{l}\text { - Over-tourism turned the heritage area into a commercial } \\
\text { seeking 'tourist-trap' } \\
\text { Businesses are all catered to foreign tourists like t-shirt, } \\
\text { souvenirs and counterfeit items. Traditional business is } \\
\text { declining in number. } \\
\text { - Petaling Street is only known among visitors for its counterfeit } \\
\text { products, not its heritage value. } \\
\text { Items sold in Petaling Street is not unique and too generic. As } \\
\text { well as those in Kasturi Walk. }\end{array}$ \\
\hline & $\begin{array}{l}\text { Decaying heritage } \\
\text { buildings }\end{array}$ & $\begin{array}{l}\text { - The roofing is blocking the heritage façade of the old buildings. } \\
\text { - } \quad \text { Lack of regulation in preserving heritage buildings. } \\
\text { Buildings owners too are not concern with the heritage value } \\
\text { of their property. }\end{array}$ \\
\hline & $\begin{array}{l}\text { Unclear on conservation } \\
\text { procedure }\end{array}$ & $\begin{array}{l}\text { - City hall lack of seriousness in conserving heritage area. } \\
\text { Conservation is only done for the sake of tourism and does not } \\
\text { follow the proper conservation discipline. } \\
\text { Conservation should be made a priority by the city hall in } \\
\text { order to maintain the image of Kuala Lumpur as a history rich, } \\
\text { multi-cultural city. }\end{array}$ \\
\hline & $\begin{array}{l}\text { The pedestrianization of } \\
\text { historical street }\end{array}$ & $\begin{array}{l}\text { Pedestrianized street should be increased in alignment with } \\
\text { the city's aim to be pedestrian friendly. } \\
\text { Pedestrian streets should not end up only selling stuff. } \\
\text { Creative activities should be introduced in the area. }\end{array}$ \\
\hline
\end{tabular}

Unsurprisingly, for the photo comparison survey, respondents from Group A prefer Photo A over Photo B, as opposed to the majority from Group $C$ who favored Photo B. When asked about the reason for Group A's preference for Photo A, they all answered 'climate factor' and 'tidier and convenience.' The result of this survey canceled this claim; "Although the stalls look untidy (multi-colored parasols), the haphazardity may be more interesting than the stereotypically similar colored stalls arranged in definitive rows," as Shuhana et al. argued [3]. As stated above, heritage is not really their concern from a business perspective.

\section{Conclusions}

The introduction of a new intervention in the Heritage Enclave should not be constrained, but must be carefully planned to create a harmonious historical environment. In order to survive the modern world and the modern way people shop, a recreation of space in the old town or a Heritage Enclave is needed. However, in order to preserve the remaining heritage buildings, a major conservation program must first be put in place before modern intervention is introduced into a sensitive area. The roofing structure, as an intervention, must therefore be designed using the best material, in order to achieve its main purpose as a shelter. A defective design not only failed to achieve its goal, but can also be an eye and money-loss project. The authority, together with the community, should therefore come up with multiple design options that respond to the historical context in Malaysia. The decline in the historical environment and the deteriorating condition of private heritage buildings in Kuala Lumpur or Malaysia is generally caused by a lack of awareness of the value of heritage among its citizens. 
The conservation of heritage concerns not only the preservation of the building façade, but also the preservation of the culture that shapes the environment of the Heritage Enclave. Traders in historic pedestrian streets are struggling to survive, and their existence is what makes the historic area valuable and therefore worth preserving.

Author Contributions: Conceptualization, A.B.; Data curation, N.A.-A.; Formal analysis, F.H., N.A.-A. and J.M.; Funding acquisition, A.B.; Investigation, F.H.; Methodology, A.B. and N.A.-A.; Project administration, A.B.; Resources, F.H. and J.M.; Visualization, F.H.; Writing—original draft, A.B., F.H. and N.A.-A.; Writing —review and editing, J.M. All authors have read and agreed to the published version of the manuscript.

Funding: Funding for this research was given under award numbers R.G.P2/75/41 by the Deanship of Scientific Research; King Khalid University, Ministry of Education, Kingdom of Saudi Arabia.

Acknowledgments: Authors thankfully acknowledge the Deanship of Scientific Research for proving administrative and financial supports.

Conflicts of Interest: The authors declare no conflict of interest.

\section{References}

1. Najib, A.A. Traditional Architectural Heritage for Modern Malaysian Buildings; Department of National Heritage, Ministry of Information, Communications and Culture: Putrajaya, Malaysia, 2013; ISBN 9789833862238. Available online: https://books.google.com.sa/books?id=k-XKoAEACAAJ (accessed on 30 April 2020).

2. Kammeier, H.D. Global Concerns-Local Responsibilities-Global and Local Benefits: The Growing Business of World Heritage. In Proceedings of the 39th ISOCARP Congress, Cairo, Egypt, 17-22 October 2003.

3. Shuhana, S.; Wan Hashimah, W.I.; Shamsuddin, S. The old shophouses as part of Malaysia urban heritage: The current Dilemma. In Proceedings of the 8th International Conference of the Asian Planning Schools Association, Rio de Janeiro, Brazil, 3-8 July 2016.

4. The Kuala Lumpur Heritage Agenda. Review \& Recommendations for the Kuala Lumpur Draft Structure Plan 2024 \& Kuala Lumpur City Plan 2020; ICOMOS Malaysia: Jalan Tandok, Malaysia, 2020.

5. Draft Kuala Lumpur Structure Plan 2040. Dewan Bandaraya Kuala Lumpur (DBKL), 2020. Available online: http://www.dbkl.gov.my/klmycity2040/klsp2040/ (accessed on 30 April 2020).

6. The Sustainable Development Goals Report 2019. United Nations, 2019. Available online: https://unstats.un. org/sdgs/report/2019/The-Sustainable-Development-Goals-Report-2019.pdf (accessed on 30 April 2020).

7. New Urban Agenda. United Nations Conference on Housing and Sustainable Urban Development (Habitat III), Equador. United Nations, 2017. Available online: http://habitat3.org/wp-content/uploads/NUAEnglish.pdf (accessed on 30 April 2020).

8. Savage, V.R. Street culture in colonial Singapore. In Public Space: Design, Use and Management; Beng-Huat, C., Edwards, N., Eds.; Singapore University Press: Singapore, 1992; pp. 11-23.

9. Ngiom; Lilian, T. 80 Years of Architecture in Malaysia; PAM Publication: Pertubuhan Akitek, Malaysia, 2000.

10. Lumpur, D.K. Dewan Bandaraya Kuala Lumpur (DBKL); City Plan 2020; Percetakan Nasional Malaysia Bhd: Kuala Lumpur, Malaysia, 2008; Volume 1.

11. Nurulhuda, A.H.Y.; Anuar, M.N.; Rosmadi, G. City skyline conservation: Sustaining the premier image of Kuala Lumpur. Procedia Environ. Sci. 2014, 20, 583-592.

12. Heritage Homeowner's Preservation Manual: World Heritage City of Vigan Philippines; UNESCO Bangkok: Bangkok, Thailand; City Government of Vigan: Vigan, Philippines, 2010; 166p, ISBN 978-92-9223-319-8. Available online: http://www.unescobkk.org/fileadmin/user_upload/library/edocuments/vigan-sample_text. pdf (accessed on 30 April 2020).

13. Elder, C. New Design in Historic Settings. Available online: https://pub-prod-sdk.azurewebsites.net/api/ (accessed on 10 August 2015).

14. Damla, M. New Designs in Historic Context: Starchitecture vs Architectural Conservation Principles; Department of Architecture, Girne American University: Kyrenia, Northern Cyprus, 2017.

15. Warren, J. The Historic Context: Principles and Philosophies. In Context: New Buildings in Historic Settings; Warren, J., Worthington, J., Taylor, S., Eds.; Architectural Press: Oxford, UK, 1998.

16. Turner, T. Landscape Planning And Environmental Impact Design; Routledge: Abingdon-on-Thames, UK, 2004. 
17. Dennis, S. Modern Architecture's place in the city: Divergent Approaches to Historical Core. In Context: New Buildings in Historic Settings; Warren, J., Worthington, J., Taylor, S., Eds.; Architectural Press: Oxford, UK, 1998.

18. Teh, L.Y. Singapore's Experience in Conservation. In Proceedings of the International Housing Conference of Hong Kong Housing Society, Hong Kong, China, 10-11 April 2008.

19. Teo, P.; Huang, S. Tourism and heritage conservation in Singapore. Ann. Tour. Res. 1995, 22, 589-615. [CrossRef]

20. Patton, M.Q. Qualitative Research and Evaluation Methods, 3rd ed.; Sage Publication: New York, NY, USA, 2002.

21. Jansen, H. The Logic of Qualitative Survey Research and its Position in the Field of Social Research Methods [63 paragraphs]. Forum Qual. Soz. Forum: Qual. Soc. Res. 2010, 11, 11.

(C) 2020 by the authors. Licensee MDPI, Basel, Switzerland. This article is an open access article distributed under the terms and conditions of the Creative Commons Attribution (CC BY) license (http://creativecommons.org/licenses/by/4.0/). 